\title{
Effects of Blended Fertilizer Rates on Bread Wheat (Triticum Aestivum L.) Varieties on Growth and Yield
}

\section{Attributes}

\author{
Rut-Duga D1', Diriba Shiferaw G²* and Wogayehu W1 \\ ${ }^{1}$ Kulumsa Agricultural Research Center, Ethiopian Institute of Agricultural Research, \\ Ethiopia \\ ${ }^{2}$ Department of Horticulture and Plant Science, Arsi University, Ethiopia
}

*Corresponding Author: Diriba Shiferaw G, Department of Horticulture and Plant

Science, College of Agriculture and Environmental Science, Arsi University, PO Box 193 Asella, Ethiopia, Email: senadiriba2012@yahoo.com

\section{Abstract}

Bread wheat (Triticum aestivum L.) is an important food crop and source of income for farmers at Tiyo district in Eastern Arsi, Ethiopia. Field experiment was conducted at Tiyo district on farmer's field in 2018 main cropping season to evaluate response of bread wheat varieties to blended (NPSB) fertilizer rates. Factorial combination of two improved bread wheat varieties (Wane and Kingbird) and eight treatments [Control, Recommended NP (150 kg ha-1 TSP $\left(69 \% \mathrm{P}_{2} \mathrm{O}_{5}\right)+158.7 \mathrm{~kg}$ ha $^{-1}$ Urea $\left.(73 \mathrm{~N})\right), 100 \mathrm{~kg}$ NPSB $\left(18.1 \mathrm{~N}+36.1 \mathrm{P}_{2} \mathrm{O}_{5}+6.7 \mathrm{~S}+0.71 \mathrm{~B}\right), 100 \mathrm{~kg} \mathrm{NPSB}+$ recommended urea $(46 \mathrm{~kg} \mathrm{~N}), 150 \mathrm{~kg}$ NPSB + recommended urea, $200 \mathrm{~kg} \mathrm{NPSB}+$ recommended urea, $250 \mathrm{~kg}$ NPSB + recommended urea, $300 \mathrm{~kg}$ NPSB + recommended urea.] were laid out in randomized complete block design with three replications. Results revealed seedling density, plant height, and harvest index were significantly affected by the main effect of fertilizer rate. Days to heading, days to maturity, spike length, seeds per spike, thousand kernel weight and straw yield were significantly affected by the main effect of varieties and fertilizers rates. Grain yield, aboveground dry biomass and number of productive tillers were significantly affected by the interaction effect of varieties and fertilizer rates. The highest seeds per spike (53.9), thousand kernel weight (37.3 g), and straw yield (9071.7 kg ha-1) were recorded from $300 \mathrm{~kg}^{-1}$ PSB ha-1 application along supplementary urea. Higher grain yield was harvested from Wane (4236 kg ha-1) variety at $300 \mathrm{~kg}$ NPSB ha-1 fertilizer rate. Therefore, application of NPSB at the rate of $300 \mathrm{~kg} \mathrm{NPSB} \mathrm{ha}^{-1}$ in the production of Wane and 200 NPSB kg ha-1 in the production of Kingbird varieties was economically beneficial and recommended for around Kulumsa area.

Keywords: Blended Fertilizers; Economic Benefit; Yield; Main Effect 


\section{Introduction}

Wheat is one of the most important crop plants in the world. It grows under a broad range of latitudes and altitudes; it is not only the most widely cultivated crop but also the most consumed food crop all over the world [1]. Wheat is one of the most important cereals cultivated in Ethiopia. Ethiopia is the largest producer of wheat in subSaharan Africa (SSA), over 1.8 million hectares annually [2]. It ranks fourth after maize, tef and sorghum both in area coverage and production [3]. Wheat production in the country is adversely affected by low soil fertility and suboptimal use of mineral fertilizers in addition to diseases, weeds, erratic rainfall distribution in lower altitude zones, and water-logging in the Vertisols areas [4].

Since its start in the early 1970's, fertilizer use in Ethiopia has focused mainly on the use and application of nitrogen and phosphorous fertilizers in the form of Urea and Di Ammonium Phosphate (DAP) for almost all crops and soil types. Such unbalanced and blanket application of plant nutrients may aggravate the depletion of other important nutrient elements in soils [5]. However, recently it is perceived that the production of such high protein cereals like wheat and legumes can be limited by the deficiency of S, B and other nutrients [6]. The current soil map based test of fertilizer recommendation indicated there is a need to add blended fertilizer under different formulation having micronutrients such as boron in Ethiopia. Boron assists absorption of nitrogen and other nutrients. Though their success rate vary from place to place, DAP was replaced by NPS since 2015 to supplement sulfur deficiency based on soil map tests.

Inappropriate cropping systems, mono cropping, nutrient mining, unbalanced nutrient application, removal of crop residues from the fields and inadequate resupplies of nutrients have contributed to decline in crop yields [7]. Low soil fertility due to monoculture cereal production systems is recognized as one of the major causes for declining per capita food production. Declining soil fertility is also an important bottleneck for smallholder cereal growers in central western parts of Ethiopia [8]. Continuous monocultures of cereals also result in reduction of yields and soil nutrients $[9,10]$. Declining yield and soil fertility as a result of continuous mono-cropping have also been reported for finger millet.

In Ethiopia, soil degradation and nutrient depletion have gradually increased in area and magnitude and have become serious threats to agricultural productivity [11].
Low soil fertility is exacerbated by soil fertility depletion through nutrient removal with harvest, tillage, weeding, and losses in runoff and soil erosion [12]. Many farmers are unable to compensate for such losses, which resulted in negative nutrient balances [13]. This situation is worsened by low input, continuous cultivation and overgrazing [12]. Supply of adequate and balanced nutrients is one way of achieving high bread wheat grain yield. Adequate and timely application of fertilizer should be aligned with fertilizer responsive varieties. This is directly associated with amount of yield harvested and thereby its end quality. Wane and Kingbird bread wheat varieties are released for their resistance against rust and early maturity. Besides genetic and environmental factors, crop management factors like fertilizer application determine productivity.

Recent studies have indicated that elements like N, P, $\mathrm{K}, \mathrm{S}$ and $\mathrm{Zn}$ levels as well as $\mathrm{B}$ and $\mathrm{Cu}$ are becoming depleted and deficiency symptoms are being observed on major crops in different areas of the country [14]. Most Ethiopian soils are deficit in macronutrients $(\mathrm{N}, \mathrm{P}, \mathrm{K}$ and S) and micronutrients ( $\mathrm{Cu}, \mathrm{B}$, and $\mathrm{Zn}$ ) [15]. The farmers in most parts of the country have limited information on the impact of different types and rates of fertilizers except blanket recommendation of nitrogen (41 kg N ha-1) and phosphorus (46 kg P205 ha-1), i.e. $50 \mathrm{~kg}$ Urea and $100 \mathrm{~kg}$ DAP ha-1 for wheat while according to the soil fertility map made over 150 districts. Except blanket recommendation of nitrogen and phosphorus, the effect of other fertilizers on yield components, yield, and grain quality of bread wheat are unknown, even though new blended fertilizers such as NPSB are currently available. The response of wheat plant to application of fertilizer varies with varieties, rainfall, soils, agronomic practices, expected yield etc. Because of that, there is a need to develop location specific recommendation on the fertilizer rates to increase the productivity of wheat. Thus, this study was initiated to evaluate the effects of blended fertilizer rates application on growth, yield and yield components of bread wheat varieties.

\section{Materials and Methods}

\section{Description of the Study Area}

The experiment was conducted at Tiyo district around Kulumsa Agricultural Research Center (KARC) on farmer field located at about $167 \mathrm{~km}$ South East of Addis Ababa, Ethiopia. Its geographical location is $8^{\circ} 02^{\prime} \mathrm{N}$ latitude and $39^{\circ} 10^{\prime}$ E longitude, representing a medium altitude at $2200 \mathrm{~m}$ above sea level with moderate rainfall of 862.7 


\section{Journal of Ecology \& Natural Resources}

mm per annum. The mean annual maximum temperature was $23.6^{\circ} \mathrm{C}$ and monthly values range between $21.3^{\circ} \mathrm{C}$ and $25.3^{\circ} \mathrm{C}$. Mean annual minimum temperature was $11.8^{\circ} \mathrm{C}$ and monthly values range between 9.7 and $13.2^{\circ} \mathrm{C}$. It has a unimodal rainfall pattern with extended rainy season from March to September. However, the peak season is from July to August (Figure 1).

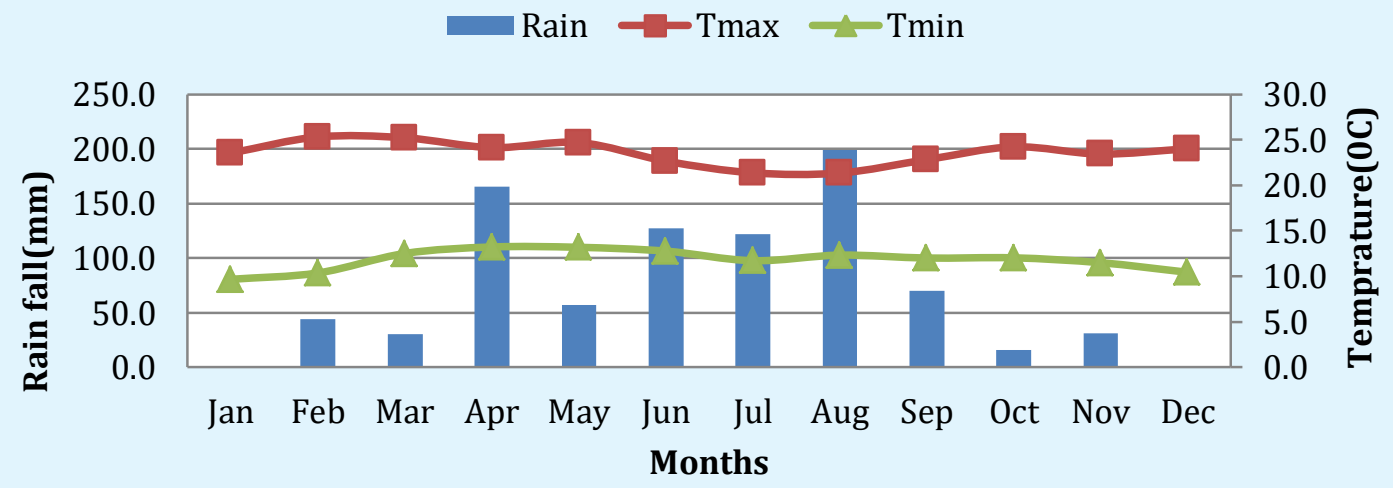

Figure 1: Mean monthly rain fall, maximum and minimum temperature of the study area in the year 2018.

\section{Experimental Materials}

Two bread wheat varieties (Wane and Kingbird) were used as planting materials. For recommend the appropriate application of NPSB blended fertilizer rate in the experimental area, these varieties were selected based on their adaptability to agro-ecological zone of the area, productivity and resistant for disease (Table 1).

\begin{tabular}{|c|c|c|c|c|c|c|c|}
\hline \multirow{2}{*}{ No } & Varieties & Year of & \multicolumn{2}{|c|}{ Area of adaptation } & \multirow{2}{*}{ Maturity days } & Agro-ecology & $\begin{array}{c}\text { On station } \\
\text { productivity (q/ha) }\end{array}$ \\
\cline { 4 - 5 } & release & Altitude(m) & Rainfall (mm) & & & & \\
\hline 1 & Wane & 2016 & $2000-2300$ & $750-1500$ & 120 & Midland & $50-65$ \\
\hline 2 & Kingbird & 2015 & $2000-2200$ & $800-1000$ & 133 & Midland & $40-50$ \\
\hline
\end{tabular}

Source: Kulumsa Agricultural Research Center (KARC), Wheat breeding program (2017).

Table 1: Descriptions of the Bread wheat varieties to be used in the experiment.

\section{Experimental Design}

The experimental design used for this experiment was Randomized Complete Block Design (RCBD) with factorial arrangement of two varieties (Wane and Kingbird) and eight fertilizer rate treatments with three replications. This gave a total of 16 treatment combinations. The gross experimental area was $49.1 \mathrm{~m} \times 14 \mathrm{~m}\left(687.4 \mathrm{~m}^{2}\right)$, Gross Plot size of $4 \mathrm{~m} \times 2.6 \mathrm{~m}\left(10.4 \mathrm{~m}^{2}\right)$ and net plot size of $3 \mathrm{~m} \times 2 \mathrm{~m}$ $\left(6 \mathrm{~m}^{2}\right)$. The spacing between rows, plots and blocks were $0.20 \mathrm{~m}, 0.5 \mathrm{~m}$ and $1 \mathrm{~m}$, respectively. By excluding the two outer rows from both sides of a plot and a $0.25 \mathrm{~m}$ row length on both ends of each plant, row of each plot to avoid border effects resulting in to a net plot size.

\section{Experimental Treatments}

The treatment includes Control (without external fertilizer application), Recommended NP $\left(150 \mathrm{~kg} \mathrm{ha}^{-1}\right.$ TSP $\left(69 \% \mathrm{P}_{2} \mathrm{O}_{5}\right)+158.7 \mathrm{~kg} \mathrm{ha}^{-1}$ Urea $\left.(73 \mathrm{~N})\right), 100 \mathrm{~kg}$ NPSB $\left(18.1 \mathrm{~N}+36.1 \mathrm{P}_{2} \mathrm{O}_{5}+6.7 \mathrm{~S}+0.71 \mathrm{~B}\right), 100 \mathrm{~kg} \mathrm{NPSB}+$ Urea (100 kg), $150 \mathrm{~kg} \mathrm{NPSB} \mathrm{+} \mathrm{Urea} \mathrm{(100} \mathrm{kg),} 200 \mathrm{~kg} \mathrm{NPSB} \mathrm{+}$ Urea (100 kg), $250 \mathrm{~kg}$ NPSB + Urea (100 kg), $300 \mathrm{~kg}$ NPSB + Urea (100 kg), (Table 2). NPSB blended fertilizer rates are applied at sawing time for all plots except control. Supplementary nitrogen fertilizer in the form of Urea was applied in two splits times to maintain the $\mathrm{N}$ requirement of the crop. This means $1 / 3$ of $100 \mathrm{~kg}$ Urea was applied two weeks after emergence and $2 / 3$ of the rest Urea was 


\section{Journal of Ecology \& Natural Resources}

applied before booting in all plots except the control and

blended alone.

\begin{tabular}{|c|c|c|c|c|}
\hline Fertilizer rates & $\mathbf{N}$ & $\mathbf{P}_{\mathbf{2}} \mathbf{O}_{5}$ & $\mathbf{S}$ & $\mathbf{B}$ \\
\hline Control & 0 & 0 & 0 & 0 \\
\hline $150 \mathrm{~kg}$ TSP + 158.7 kg Urea h-1 & 73 & 69 & 0 & 0 \\
\hline $100 \mathrm{~kg} \mathrm{NPSB}+0 \mathrm{~kg} \mathrm{Urea} \mathrm{ha}^{-1}$ & 18.1 & 36.1 & 6.7 & 0.71 \\
\hline $100 \mathrm{~kg} \mathrm{NPSB}+100 \mathrm{~kg} \mathrm{Urea} \mathrm{ha}^{-1}$ & 64.1 & 36.1 & 6.7 & 0.71 \\
\hline $150 \mathrm{~kg} \mathrm{NPSB}+100 \mathrm{~kg} \mathrm{Urea} \mathrm{ha}^{-1}$ & 73.15 & 54.15 & 10.05 & 1.07 \\
\hline $200 \mathrm{~kg} \mathrm{NPSB}+100 \mathrm{~kg} \mathrm{Urea} \mathrm{ha}^{-1}$ & 82.2 & 72.2 & 13.4 & 1.42 \\
\hline $250 \mathrm{~kg} \mathrm{NPSB}+100 \mathrm{~kg} \mathrm{Urea} \mathrm{ha}^{-1}$ & 91.25 & 90.25 & 16.75 & 1.78 \\
\hline $300 \mathrm{~kg} \mathrm{NPSB}+100 \mathrm{~kg} \mathrm{Urea} \mathrm{ha}^{-1}$ & 100.3 & 108.3 & 20.1 & 2.13 \\
\hline
\end{tabular}

N: Nitrogen; $\mathrm{P}_{2} \mathrm{O}_{5}$ : di phosphorus pento Oxide; S: Sulfur; B: Boron; TSP: Triple Super Phosphate; and NPSB: Nitrogen Phosphorus Sulfur and Boron

Table 2: Fertilizer treatment rates used and their nutrient contents for the experiment.

\section{Data collection and measurements}

\section{Soil Physico-chemical Property}

Soil pH was measured in 1:2.5 soil: water suspension using digital $\mathrm{pH}$ meter (Systronics make) having glass electrode as described by Jackson.

Organic matter was determined using traditional wet digestion with acid-dichrome and heat modified WalkelyBlack.

Total $\mathbf{N}$ was determined by using Kjeldahl method.

Available sulfur was determined by using Available sulfur in the form of sulphate and determined by using $0.15 \% \quad \mathrm{CaCl}_{2}$ as extractant and measured turbidometrically using spectrophotometer at $420 \mathrm{~nm}$.

Available Boron was determined by using Spectrophotometer that can measure absorbance at a wavelength of $420 \mathrm{~nm}$, using dilute $\mathrm{HCl}$ method of Ponnamperuma, et al.

Available $\mathbf{P}$ was using extracting solution $\left(0.03 \mathrm{M} \mathrm{NH}_{4} \mathrm{~F}\right.$ and $0.1 \mathrm{MHCl}$ ) for extracted a sample from the soil using Bray II methods and using procedures described by Bary and Kurtz [16].

Cation Exchangeable Capacity (CEC) was determined by using the $\mathrm{NH}_{4} \mathrm{AC} \mathrm{pH} 7.0$ methods. It was measuring the total amount of a given cation equilibrating the charge of the exchanger Landon [17].

Texture or particle size was determined using the Bouyoucos hydrometer method.

Bulk density was determined by Core sampler method Arshad MA, et al. (1997)

\section{Crop Phonology and Growth Parameters}

Emergency Date: It was determined from the time of sowing until $50 \%$ germination
Seedling density: was counted seedlings of planted materials after two weeks of sowing between $50 \mathrm{~cm}$ of the net plot area of each treatments

Number of productive tillers: was determined at maturity by counting all spikes bearing kernels from ten randomly pre-tagged plants per net plot at full tillering stage and then the mean was determined.

Days to heading: was taken when the ears or panicles fully visible on $50 \%$ of the plants from each plot by visual observation.

Days to Physiological maturity: Days to physiological maturity was recorded as the number of days from date of sowing till in $90 \%$ of the plants changed their green color to yellowish, in each plot.

Spike length: was recorded at physiological maturity stage by measuring the middle rows of ten (10) randomly tagged plants from the base of the spike to the tip of the spike (excluding the awns) and the average of the plant taken was calculated.

Plant height: was recorded when the crop reached physiological maturity by measuring the middle rows of ten (10) randomly tagged plants from the base of the land to the tip of the spike (awns excluded) and the average of the plant taken was calculated.

\section{Yield and Yield Components}

Number of kernels per spike: Number of kernels per spike was determined from the ten randomly sampled spikes from the net plot.

Thousand Kernel weight (g): It was determined the weight of 1000 full sized kernels sample from the grain yields for each treatment, using an electric seed counter, weighing with an electronic balance and adjusted to $12.5 \%$ moisture level. 
Moisture content (MC): Moisture content of grain was determined by Near Infra-Red Spectroscopy (AACC 2000) [18].

Grain yield (kgha-1): The grain yield was taken by harvesting and threshing the grain yield from net plot area and converted to $\mathrm{kg} \mathrm{ha}^{-1}$. The yield was adjusted to $12.5 \%$ moisture.

The above ground dry biomass (BY): was determined from plants harvested from the net plot area after sun drying to a constant weight and converted to kg per hectare.

Straw yield (SY): was obtained by subtracting grain yield from the total above ground dry biomass yield for respective treatment and expressed in $\mathrm{kg} \mathrm{ha}^{-1}$.

Harvest Index (HI): it was the ratio of dried grain weight to the dried total above ground biomass weight per plot multiplied by 100 .

\section{Data Analysis}

The data obtained from the field were subjected to analysis of variance (ANOVA) using SAS, version 9.0, General linear model procedures [19] and mean separation was by least significant difference (LSD) test.

\section{Results and Discussion}

\section{Selected Physicochemical Properties of Experimental Soil before Sowing}

Soil $\mathbf{P H}^{\mathbf{H}}$ results were found to be moderately acidic Vertisols with a pH value of 6.17 which is indicated at (Table 3). According to EthioSIS [20] pH values classified as < 4.5 strongly acidic, 4.5-5.5 highly acidic, 5.6-6.5 moderately acidic, 6.6-7.3 neutral, 7.4-8.4 moderately alkaline, $>8.5$ strongly alkaline. The $\mathrm{pH}$ of the soil between (5.00-7.55) was found within the suitable range for crop production [21]. So that the $\mathrm{pH}$ level of the study is conducive for wheat production as normal soil $\mathrm{pH}$ for wheat is recorded to be from $\mathrm{pH}$ of 6.25 - 7.5 arrange appropriate condition for most wheat verities [22].

Organic Carbon: The area of soil organic carbon content was $1.76 \%$ having the organic matter content of $3.03 \%$ (with conversion factor of 1.724) (Table 3). Soil organic carbon percentages of $<0.60,0.6-1.0,1.0-1.80,1.80$ 3.0 , and $>3$ as very low, low, medium, high, and very high, respectively EthioSIS [20]. According to Tekalign [23] rating, organic matter content of the soil is very low $(<0.86 \%$ ), low ( 0.86 to 2.59 ), medium ( 2.59 to 5.17 ), high (>5.17), and very high (not given). The experimental site can be classified in medium range. According to Booker [17] total OC \% of the soil greater than 10 was rated as high, $4-10$ as medium and less than 4 as low. Azlan, et al. [24] reported that soil texture influence the rate of soil organic matter (SOM) decomposition. The low organic matter content of the soil could influence the release and availability of nutrients in the subsequent cropping season.

Total Nitrogen: Total nitrogen value of the experimental soil was (0.11). According to EthioSIS [15] TN content $<0.1,0.1-0.15,0.15-0.3,0.3-0.5$, and $>0.5$ was very low, low, medium, high and very high, respectively. The result indicated $\mathrm{N}$ is limiting factor for crop growth. The optimum $\mathrm{N}$ level needed for crop production under most soils of Ethiopia is reported to be $<0.2 \%$ according to EthioSIS [20]. Tekalign, et al. [23] classified soil according to $\mathrm{N}$ availability as very low, poor, moderate and high with $<0.05 \%, 0.05-0.12 \%, 0.12-0.25 \%$ and $>0.25 \%$, respectively. Generally the high nitrogen content of the soil might be due to high vegetation cover, virgin land and high crop residue from the fields.

Available Phosphorus: available $\mathrm{P}$ content of the experimental sit was (8.21) (Table 3). According to Bray [16] the range of phosphorus in Bray method is $<7,8-19$, 20-39, 40-58 and $>59$ was very low, low, medium, high and very high, respectively. EthioSIS [15] suggest optimum P content for most Ethiopian soil as $15 \mathrm{mg} \mathrm{kg}^{-1}$. Based on this, the available phosphorous of the study area is low and needs phosphorous fertilizer. This low phosphorous content is due to intensive mining of the farm fields and fixation by heavy metal captions. Masresha [25] also reported low amount of P content on soils which are cultivated repeatedly due to $P$ fixation and P mining. Similarly, Habtamu, et al. [26] reported that low contain of $\mathrm{P}$ was due to fixation problem.

Cation Exchange Capacity: The CEC of the site was 22.86 $\mathrm{cmol} \mathrm{kg}^{-1}$ (Table 3). Landon, et al. [17] reported that soils having CEC of $>40,25-40,15-25,5-15,<5 \mathrm{cmol} \mathrm{kg}^{-1}$ categorized as very high, high, medium, low and very low, respectively. According to the result obtained from soil laboratory, the value of CEC was in medium range.

Available Boron: Available Boron in the study area was $0.43 \mathrm{mg} \mathrm{kg}^{-1}$ (Table 3). EthioSIS [20], critical B value for most Ethiopian soils is $0.8 \mathrm{mg} \mathrm{kg}^{-1}$. This shows that soils of the study area are deficit in B suggesting application of fertilizer which contains B. Intensive cultivation in the area was responsible for low B content of the soil.

Available Sulfur: Available sulfur value of the study area was $2.09 \mathrm{mg} \mathrm{kg}^{-1}$ (Table 3). Based on EthioSIS [15] soil 
classification for $\mathrm{S}$ values lies on very low range. The classification is $<9$ very low, 10-20 low, 20-80 optimum, and $>80 \mathrm{mg} \mathrm{kg}-1$ high. So addition of fertilizer which contains $\mathrm{S}$ is relevant. This low in sulfur content of the soil may be due to loss of $\mathrm{OM}$ and lacking of using S source mineral fertilizer. It was also related to continuous cultivation which result intensive mining of $S$ from the soil.
Bulk density: Bulk density of the experimental site was $0.85 \mathrm{~g} \mathrm{~cm}^{-3}$ (Table 3). White RE [27] stated that values of bulk density ranges from $<1 \mathrm{~g} \mathrm{~cm}^{-3}$ for soils high in $\mathrm{OM}$, 1.0 to $1.4 \mathrm{~g} \mathrm{~cm}^{-3}$ for well- aggregated loamy soils and 1.4 to $1.8 \mathrm{~g} \mathrm{~cm}^{-3}$ for sands and compacted horizons in clay soils. Based on these soils of the study area were good for production with regarding to bulk density. Mohammed YA, et al. [28] who found decrease in bulk density as a result of nutrient and crop management.

\begin{tabular}{|c|c|c|c|c|}
\hline Soil Parameter & Unit & Value & Rates & Methology \\
\hline \multicolumn{5}{|c|}{ Particle size distribution } \\
\hline Sand & $\%$ & 11.25 & & \\
\hline Silt & $\%$ & 39.75 & & \\
\hline Clay & $\%$ & 49 & & \\
\hline Textural class & & Clay & & Hydrometer \\
\hline BD & $\mathrm{g} / \mathrm{cm}^{3}$ & 0.85 & Best & Core sampler \\
\hline $\mathrm{PH}^{\mathrm{H}}$ & $\%$ & 6.17 & Slightly acidic & Potentiometric \\
\hline OC & $\%$ & 1.76 & Low & Walkley and Black \\
\hline TN & $\%$ & 0.11 & Low & Kjeldak \\
\hline $\mathrm{AP}$ & $\mathrm{mg} \mathrm{kg}^{-1}$ & 7.67 & Low & Bray II \\
\hline $\mathrm{AB}$ & $\mathrm{mg} \mathrm{kg}^{-1}$ & 0.43 & Low & Hydrochloric Acid \\
\hline AS & $\mathrm{mg} \mathrm{kg}^{-1}$ & 2.09 & Low & Turbidimetric \\
\hline CEC & $\mathrm{meq} / 100 \mathrm{~g}$ & 22.86 & Medium & Ammonium acetate \\
\hline
\end{tabular}

BD: Bulk Density; OC: Organic Carbon; OM: Organic Matter; TN: Total Nitrogen; AP: Available Phosphorous; AB: Available Boron; AS: Available sulfur; CEC: Cation Exchange Capacity.

Table 3: Selected soil physico-chemical properties of the Study areas before sowing.

\section{Effects of Blended Fertilizer Rates and Variety on Phonological and Growth Variables}

Days to heading and maturity were significantly $(\mathrm{P}<0.01)$ affected by the main effect of wheat varieties having longer days to heading (69.1) and Days to physiological maturity (112.3) period on kingbird variety as compared to Wane (63.9) and (107.3) respectively (Table 4). The longest days to heading (71.7) and physiological maturity (113.0) was observed for both varieties at $300 \mathrm{Kg}$ of NPSB application with supplementary urea. The shortest dates of heading and physiological maturity were observed for both varieties (61.3) and (106.2) at control, respectively. This difference could be attributed to the application different rates of blended fertilizer rates for bread wheat varieties. These results were in line with Bekalu \& Mamo [29] who reported that, $\mathrm{N}$ fertilizer rate significantly affected days to maturity on wheat. The results are similar to Marschener [30]. Who observed when $\mathrm{N}$ is applied in excess; the maturity of the crop is delayed by affecting the supply of photosynthesis during critical period of the reproductive phase. Moreover, when $\mathrm{N}$ is applied in excess to wheat, the sugar concentration in leaves gets reduced during early ripening stage and hence, inhibition occurs in the translocation of assimilated products to spikelet [31].

Main effect of blended fertilizer rates also significantly influenced seedling density and plant height (Table 4). The lowest results of these growth parameters were recorded from the control plot; but most seedling density and largest plant height were obtained from the highest NPSB (300 kg ha-1) application along with $100 \mathrm{~kg} \mathrm{ha}^{-1}$ of urea. Most of the growth parameters results were increased along the application rates of NPSB when supplemented with urea fertilizer. The highest plant height $(95.5 \mathrm{~cm})$ was recorded from the plot treated with the highest blended Fertilizer rate of $300 \mathrm{Kg}$ of NPSB application, while the shortest plant height $(75.6 \mathrm{~cm})$ was obtained from the control plot (Table 4). The result showed that plant height increases at an increasing rate of nitrogen levels. Similar results of plant height increment with $\mathrm{N}$ rate increase were also reported by Ali $\mathrm{L}$, et al. [32]. Tayebeh, et al. [33] and Sofonyas [34] reported 


\section{Journal of Ecology \& Natural Resources}

significant increments in plant height due to application

of high nitrogen rate.

\begin{tabular}{|c|c|c|c|c|c|}
\hline Varieties & ED & SD & DH & DM & PH(cm) \\
\hline Wane & 6.0 & 22.9 & $63.9^{b}$ & $107.3^{\mathrm{b}}$ & 88.6 \\
\hline Kingbird & 6.0 & 23 & $69.1^{\mathrm{a}}$ & $112.3^{\mathrm{a}}$ & 89.2 \\
\hline LSD (\%) & NS & NS & 1.36 & 0.75 & NS \\
\hline \multicolumn{6}{|l|}{ Fertilizer rates $\left(\mathrm{kg} \mathrm{ha}^{-1}\right)$} \\
\hline $0 \mathrm{~kg} \mathrm{~F} \mathrm{ha}^{-1}$ & 6.2 & $21.1^{\mathrm{c}}$ & $61.3^{\mathrm{d}}$ & $106.2^{\mathrm{c}}$ & $75.6^{f}$ \\
\hline 150 kg TSP + 158.7 kg Urea h${ }^{-1}$ & 6.0 & $23.4^{\mathrm{ab}}$ & $68.0^{\mathrm{bc}}$ & $109.7^{b}$ & $90.5^{\text {cd }}$ \\
\hline 100 kg NPSB + 0 kg Urea ha-1 & 6.0 & $22.7 \mathrm{ab}$ & $61.0^{\mathrm{d}}$ & $106.7 \mathrm{c}$ & $83.0 \mathrm{e}$ \\
\hline $100 \mathrm{~kg}$ NPSB $+100 \mathrm{~kg}^{2}$ Urea ha $^{-1}$ & 6.0 & $23.4^{\mathrm{ab}}$ & $63.3^{\mathrm{d}}$ & $108.8^{\mathrm{b}}$ & $87.6^{\mathrm{d}}$ \\
\hline 150 kg NPSB + 100 kg Urea ha $^{-1}$ & 6.0 & $22.8^{\mathrm{ab}}$ & $66.5^{c}$ & $109.8^{\mathrm{b}}$ & $92.3^{\mathrm{bc}}$ \\
\hline 200 kg NPSB + 100 kg Urea ha $^{-1}$ & 6.2 & $23.2^{\mathrm{ab}}$ & $69.7 \mathrm{ab}$ & $112.3^{\mathrm{a}}$ & $92.6^{\mathrm{bc}}$ \\
\hline 250 kg NPSB + $100 \mathrm{~kg}^{2}$ Urea ha $^{-1}$ & 6.0 & $23.4^{\mathrm{ab}}$ & $70.7^{\mathrm{a}}$ & $112.0^{\mathrm{a}}$ & $94.5^{\mathrm{ab}}$ \\
\hline $300 \mathrm{~kg}$ NPSB $+100 \mathrm{~kg}^{\prime}$ Urea ha $^{-1}$ & 6.0 & $23.6^{\mathrm{a}}$ & $71.7^{\mathrm{a}}$ & $113.0^{\mathrm{a}}$ & $95.5^{\mathrm{a}}$ \\
\hline LSD (5\%) & NS & 0.92 & 2.72 & 1.49 & 3.18 \\
\hline P Value & 0.4600 & 0.0814 & $<.0001$ & $<.0001$ & $<.0001$ \\
\hline CV (\%) & 3.26 & 3.25 & 3.30 & 1.1 & 2.89 \\
\hline
\end{tabular}

ED: Emergency date; SD: Seedling density; DH: Days to heading; DM: Days to physiological maturity; PH: Plant height; TSP: Triple Super Phosphate; NPSB: Nitrogen Phosphorus Sulfur and Boron

Table 4: Main effect of variety and blended fertilizer rate on emergency date, seedling density, days to heading, days to physiological maturity and plant height.

\section{Yield and Yield Components}

Number of productive tillers per plant: Number of productive tillers per plant were significantly $(\mathrm{P}<0.01)$ influenced by the interaction effect of varieties and fertilizer rates. Accordingly, Wane variety had better performance than Kingbird variety (Table 5). The response of the crop in terms of number of effective tillers in Wane (7.7) and Kingbird (6.0) varieties were higher at $300 \mathrm{Kg}$ of NPSB application with supplementary urea. Wane variety at $200 \mathrm{~kg}$ NPSB (7.0), $250 \mathrm{~kg}$ NPSB (7.3) and $300 \mathrm{~kg}$ NPSB (7.7) fertilizer rates with supplementary urea applications was statistically non-significant. The lowest numbers of effective tillers (4.4) were recorded for both varieties at control plot; which might be due to the role of $\mathrm{N}$ in accelerating vegetative growth of plants. The highest result of Wane and Kingbird were improved by $42.9 \%$ and $26.7 \%$ respectively as compared to the lowest number of productive tillers per plant at control. The results were in agreement with that of Abdullatif, et al. [35] who reported that increasing in the number of effective tillers with nitrogen fertilization. Bereket, et al. [36] and Abdollahi, et al. [37] also reported that nitrogen fertilization have significant effect on effective number of tillers of wheat.

Diriba Shiferaw G, et al. Effects of Blended Fertilizer Rates on Bread Wheat (Triticum Aestivum L.) Varieties on Growth and Yield Attributes. J Ecol \& Nat Resour 2019, 3(3): 000170.

\begin{tabular}{|c|c|c|}
\hline \multicolumn{3}{|c|}{ Number of Productive Tillers } \\
\hline \multirow[t]{2}{*}{ Fertilizer rates $\left(\mathrm{kg} \mathrm{ha}^{-1}\right)$} & \multicolumn{2}{|c|}{ Varieties } \\
\hline & Wane & Kingbird \\
\hline $0 \mathrm{~kg} \mathrm{~F} \mathrm{ha}^{-1}$ & $4.4 \mathrm{fg}$ & $4.4 \mathrm{fg}$ \\
\hline $150 \mathrm{~kg}$ TSP + $158.7 \mathrm{~kg}$ Urea h$^{-1}$ & $5.8^{\mathrm{bc}}$ & $4.8^{\mathrm{efg}}$ \\
\hline $100 \mathrm{~kg}$ NPSB + 0 kg Urea ha-1 & $4.8^{\mathrm{efg}}$ & $4.8^{\mathrm{efg}}$ \\
\hline $100 \mathrm{~kg}^{2} \mathrm{NPSB}+100 \mathrm{~kg}^{\prime} \mathrm{Ura} \mathrm{ha}^{-1}$ & $4.8^{\mathrm{efg}}$ & $5.2^{\text {cde }}$ \\
\hline $150 \mathrm{~kg}$ NPSB $+100 \mathrm{~kg}^{2}$ Urea ha-1 & $5.1 \mathrm{~d}^{\mathrm{def}}$ & 5.0 defg \\
\hline $200 \mathrm{~kg}$ NPSB $+100 \mathrm{~kg}^{\prime}$ Urea ha-1 & $7.0^{\mathrm{a}}$ & $5.1^{\mathrm{def}}$ \\
\hline $250 \mathrm{~kg}$ NPSB $+100 \mathrm{~kg}^{\prime}$ Urea ha ${ }^{-1}$ & $7.3^{\mathrm{a}}$ & $5.5^{\mathrm{bcd}}$ \\
\hline $300 \mathrm{~kg}$ NPSB $+100 \mathrm{~kg}^{2}$ Urea ha ${ }^{-1}$ & $7.7^{\mathrm{a}}$ & $6.0^{\mathrm{b}}$ \\
\hline Grand mean & \multicolumn{2}{|c|}{5.47} \\
\hline LSD (5\%) & \multicolumn{2}{|c|}{0.67} \\
\hline P value & \multicolumn{2}{|c|}{$<.0001$} \\
\hline CV (\%) & \multicolumn{2}{|c|}{7.33} \\
\hline
\end{tabular}

Table 5: Mean values of the interaction effect of blended fertilizer rates and bread wheat varieties on productive tillers.

TSP: Triple Super Phosphate; NPSB: Nitrogen Phosphorus Sulfur and Boron; LSD: Least Significant Difference; CV: Critical Value. Means followed by the same letter(s) within a column are not significantly different from each other at $5 \%$ level of significance, ns: Not significant. 
Spike length: Spike length was significantly $(p<0.01)$ influenced by the main effects of blended fertilizer rate and Varieties, but not for their interaction. Kingbird Variety $(7.3 \mathrm{~cm})$ had higher spike length as Compared to Wane variety $(6.5 \mathrm{~cm})$. The highest spike length $(7.3 \mathrm{~cm})$ was recorded from the plot treated with $300 \mathrm{~kg} \mathrm{ha}^{-1}$ of NPSB application which improved by $12 \%$ as compared the shortest spike length $(6.4 \mathrm{~cm})$ obtained from the control plot (Table 6). According to the experiment the application of mixed blended fertilizer rates along supplementary nitrogen were significantly influenced as compared to the control plot. Bekalu \& Mamo [29] reported that optimum amount of fertilizer application has significant effect on spike length growth.

Number of Seeds per Spike: The analysis of variance showed that number of seeds per spike was significantly $(\mathrm{P}<0.01)$ affected by the main effects of blended fertilizer rates and varieties, but their interactions was no significantly influenced. Higher number of seeds per spike (45.2) was recorded from Wane variety as compared to Kingbird variety (43.1) (Table 6). Lower number of seeds per spike was recorded in control plot and recommended NPSB only (100 kg ha-1) as compared to those plots fertilized with NPSB along supplementary urea. Number of seed per spike becomes significantly increased as the rate of NPSB application increased from 0 to $300 \mathrm{~kg} \mathrm{ha}^{-1}$. When compared to the recommended rate of NPSB fertilizer and control, the blended fertilizer rates applied at 250 and $300 \mathrm{~kg}$ NPSB significantly increased number of seeds per spike by $35 \%$ and $38 \%$ and by $37 \%$ and $40 \%$, respectively for Wane and Kingbird varieties (Table 6). This might be due to the addition of blended fertilizer application rates in the experimental site there was increased the appearance of seeds in their spikes. The results were in conformity with that of Tayebeh, et al. [33] who stated that increasing $\mathrm{N}$ rates up to optimum level significantly increased number of seed spike-1. Number of grain per spike is an important yield participating parameter and has a direct consequence on the grain yield of wheat [38].

Thousand Kernel weight: The analysis of variance showed that the main effect of varieties and blended fertilizer rates significantly $(\mathrm{p}<0.01)$ affected thousand kernel weight (TKW), but there was no interaction effect. Wane Variety (37.0 gm) was recorded more than Kingbird variety (35.3 gm) in TKW. The highest TKW (37.3g) was produced by the application of $300 \mathrm{~kg} \mathrm{ha}^{-1}$ NPSB while in most fertilizer treatments there was no significant difference (Table 6). The lowest TKW was recorded from control which was decreased by $9 \%$ and $8 \%$, respectively from the highest thousand seed weight produced from those fertilized by $300 \mathrm{~kg} \mathrm{ha}^{-1}$ NPSB. The application of increasing blended fertilizer rates in the experimental area increased the seeds size and the amount of powder of bread wheat varieties. Because of that TKW of each treatment were different. Tayebeh, et al. [33] who reported number seeds spike ${ }^{-1}$ and 1000 grain weight were significantly enhanced by increasing nitrogen levels. Higher seed weight is a reflection of improved nutrient use efficiency as a result of increased application of nitrogen level and blended fertilizer, respectively. This is in line with Muhammad, et al. [39], who reported that applying both micro (especially $\mathrm{Zn}, \mathrm{B}$ ) and macro nutrient and when $\mathrm{N}$-level application increase there is a positive impact on yield component of wheat crop especially on 1000 seed weight. This result is harmony with Shuaib, et al. [40] who said when applying micro (especially Zn,B) and macro nutrient and when $\mathrm{N}$-level application increase there is a positive impact on yield component of wheat crop especially on 1000 seed weight.

Straw yield: The main effect of variety and blended fertilizer rate exhibited significant $(p<0.05)$ differences in straw yield, but their interaction was not significant. Wane variety (6349 $\mathrm{kg} \mathrm{ha}^{-1}$ ) was more productive than Kingbird variety $\left(5970 \mathrm{~kg} \mathrm{ha}^{-1}\right)$. The highest production of straw yield (9072 $\mathrm{kg} \mathrm{ha}^{-1}$ ) was recorded when fertilized by $300 \mathrm{~kg}$ NPSB and the lowest (3099 kg ha-1) was from the control (Table 6). Wheat treated with $200 \mathrm{~kg}$ NPSB (7338 kg ha-1) $250 \mathrm{~kg}$ NPSB (8056 kg ha-1) and $300 \mathrm{~kg}$ NPSB (9072 $\mathrm{kg} \mathrm{ha}^{-1}$ ) fertilizer rates were significantly different from the recommended NP (6270 kg ha-1) applied (Table 6). This difference might be attributed to the higher productivity of yield and yield components of Wane variety (Table 1). According to Abebe, straw yield increased with increasing the fertilizer rates, whereby the lowest and nitrogen increases vegetative growth of plants, especially at higher doses. Besides, the significant increase in plant height, spike length and number of fertile tillers by $\mathrm{N}$ rate contributed to the significant increase in straw yield. Bereket, et al. [36] also reported that wheat straw yield increased with $\mathrm{N}$ rates.

Harvest index: The analysis of variance for harvest index showed that main effect of blended fertilizer rates were significantly $(\mathrm{p}<0.01)$ affected, but not for varieties and their interaction effects. The control treatment had resulted in the highest harvest index $(40.1 \%)$ and the lowest (30.4\%) was those fertilized by $300 \mathrm{~kg}$ NPSB (Table 6). Reductions in HI relative to the control were $8.5 \%, 15.2 \%, 20.2 \%$ and $24.2 \%$ due to recommended NP, 200, 250and $300 \mathrm{~kg}$ blended fertilizer rate treatments, 
respectively. Fertilizer rate treatments significantly reduced harvest index as compared to the control. According to Jemal, et al. [41], significant varietal differences on harvest index in bread wheat varieties were reported. A mean harvest index of about $50 \%$ with a positive trend due to increasing $\mathrm{N}$ rate was previously reported in Ethiopia [42]. In contrast, Marcelo, et al. [43] reported that rates and sources of $\mathrm{N}$ did not affect harvest index of wheat.

\begin{tabular}{|c|c|c|c|c|c|}
\hline Varieties & SL & SPS & TKW & HI & SY \\
\hline & $(\mathrm{cm})$ & (No) & (gm) & $(\%)$ & $\left(\mathrm{kg} \mathrm{ha}^{-1}\right)$ \\
\hline Wane & $6.5^{\mathrm{b}}$ & $45.2^{\mathrm{a}}$ & $37.0^{\mathrm{a}}$ & 36.24 & $6349 \mathrm{a}$ \\
\hline Kingbird & $7.3^{\mathrm{a}}$ & $43.1^{\mathrm{b}}$ & $35.3^{\mathrm{b}}$ & 36.17 & $5970^{\mathrm{b}}$ \\
\hline LSD & 0.14 & 0.75 & 0.73 & NS & 363.06 \\
\hline $0 \mathrm{~kg} \mathrm{~F} / \mathrm{ha}$ & $6.4^{\mathrm{d}}$ & $32.3^{\mathrm{e}}$ & $33.9^{c}$ & $40.1^{\mathrm{a}}$ & $3099^{f}$ \\
\hline 150 kg TSP + $158.7 \mathrm{~kg}$ Urea h$^{-1}$ & $7.0^{\mathrm{ab}}$ & $48.2^{\mathrm{b}}$ & $36.9^{\mathrm{ab}}$ & $36.7 \mathrm{bc}$ & $6270^{c}$ \\
\hline $100 \mathrm{~kg}$ NPSB + 0 kg Urea ha-1 & $6.6^{\mathrm{cd}}$ & $34.0^{\mathrm{e}}$ & $34.4^{\mathrm{c}}$ & $39.7^{\mathrm{ab}}$ & $4284 \mathrm{e}^{\mathrm{e}}$ \\
\hline 100 kg NPSB + 100 kg Urea ha-1 & $6.9 \mathrm{bc}$ & $39.9^{\mathrm{d}}$ & $35.9^{\mathrm{b}}$ & $39.7 \mathrm{ab}$ & $5090^{\mathrm{d}}$ \\
\hline 150 kg NPSB + 100 kg Urea ha-1 & $6.9^{\mathrm{bc}}$ & $44.5^{\mathrm{c}}$ & $36.7^{\mathrm{ab}}$ & $37.1^{\mathrm{abc}}$ & $5867^{c}$ \\
\hline 200 kg NPSB + 100 kg Urea ha-1 & $7.1^{\mathrm{ab}}$ & $48.3^{\mathrm{b}}$ & $36.8^{\mathrm{ab}}$ & $34.0^{\mathrm{cd}}$ & $7538^{\mathrm{b}}$ \\
\hline 250 kg NPSB + 100 kg Urea ha-1 & $6.9^{\mathrm{bc}}$ & $52.2^{\mathrm{a}}$ & $37.2^{\mathrm{ab}}$ & $32.0^{\text {de }}$ & $8056^{\mathrm{b}}$ \\
\hline 300 kg NPSB + 100 kg Urea ha-1 & $7.3^{\mathrm{a}}$ & $53.9^{a}$ & $37.3^{\mathrm{a}}$ & $30.4 \mathrm{e}$ & $9072^{a}$ \\
\hline LSD & 0.3 & 1.49 & 1.45 & 3.28 & 726.07 \\
\hline P Value & 0.0001 & $<.0001$ & 0.0076 & 0.0106 & $<.0001$ \\
\hline CV (\%) & 3.5 & 2.73 & 3.24 & 7.31 & 9.52 \\
\hline
\end{tabular}

Table 6: Main effect of variety and blended fertilizer rate on Spick length, Seeds per spike and thousand kernel weight. SL: Spike length; SPS: Seeds per spick; TKW: Thousand kernel weight; HI: Harvest index; SY: Straw yield; TSP: Triple Super Phosphate; NPSB: Nitrogen Phosphorus Sulfur and Boron; LSD: Least Significant Difference; CV: Critical Value. Means followed by the same letter(s) within a column are not significantly different from each other at $5 \%$ level of significance, ns: Not significant.

Grain yield: The interactions between varieties and blended fertilizer rates were found to be significantly $(\mathrm{P}<$ $0.05)$ affected grain yield. These indicating that the varieties grain yield was differently influenced by fertilizer rate. Data for mean grain yield was presented (Table 7). The ultimate goal in crop production is maximum economic yield, which is a complex function of individual yield components in response to the genetic potential of the varieties and inputs used. Wane variety showed better performance of grain yield $\left(4236 \mathrm{~kg} \mathrm{ha}^{-1}\right)$ at the highest rate of $300 \mathrm{~kg}$ NPSB fertilizer application which might be due to the highest response of cultivars to $\mathrm{N}$ and use efficiency, and the lowest grain yield $2165 \mathrm{~kg}$ ha $^{-1}$ ) was also recorded from control. But for Kingbird variety showed better performance of grain yield $(3737 \mathrm{~kg}$ $\mathrm{ha}^{-1}$ ) at $200 \mathrm{~kg}$ NPSB fertilizer application and the lowest yield (1991 $\mathrm{kg} \mathrm{ha}^{-1}$ ) at control. The grain yield obtained from Wane variety at $200 \mathrm{~kg}$ NPSB (3966 kg ha-1), $250 \mathrm{~kg}$ NPSB (4107 kg ha-1) and $300 \mathrm{~kg}$ NPSB (4236kg ha-1) fertilizer rates applications was statistically nonsignificant from each other but there was significant difference from the recommended NP (3562 kg ha-1) (Table 7). Variety Kingbird was statistically not- significant difference between the treatments recommended NP (3647 $\left.\mathrm{kg} \mathrm{ha}^{-1}\right), 200 \mathrm{~kg}$ NPSB (3737 kg $\mathrm{ha}^{-1}$ ), $250 \mathrm{~kg}$ NPSB (3499 $\left.\mathrm{kg} \mathrm{ha}^{-1}\right)$ and $300 \mathrm{~kg}$ NPSB (3682 $\mathrm{kg} \mathrm{ha}^{-1}$ ). The highest result of Wane and Kingbird were improved by $48.9 \%$ and $46.7 \%$, respectively as compared to the lowest grain yield produced from control; and by $33.8 \%$ and $24.1 \%$ as compared to recommended NPSB alone for Wane and Kingbird varieties, respectively. Increasing the application of blended fertilizer rates on the production of bread wheat varieties produce different amounts of yield in the experimental site. Bereket, et al. [36] also reported that increasing rate of nitrogen fertilization increased grain yield of wheat. Similarly, Mulugeta, et al. [44] reported that application of nutrients like $\mathrm{K}, \mathrm{S}, \mathrm{Zn}, \mathrm{Mg}$ and B significantly increased grain yield and yield component of bread wheat as compare to the control (no fertilizer).

Above ground biomass yield: The analysis of variance showed highly significant $(\mathrm{P}<0.01)$ differences in above ground biomass yield that affected by the interaction effect of blended fertilizer rates and varieties. The highest production of above ground biomass yield in Wane 
(14053 kg ha-1) and Kingbird varieties (12009 kg ha-1) were recorded from those plants fertilized with $300 \mathrm{~kg}$ NPSB and the lowest (5302 kg ha-1) and (5303 kg ha-1) was obtained from the control treatments of the two varieties, respectively (Table 7). The above ground biomass yield obtained from Wane variety at $300 \mathrm{~kg}$ NPSB (14053kg ha-1) was significantly different from other fertilizer treatments. On the other hand, Kingbird variety was statistically not-significantly different between the fertilizer treatments of $200 \mathrm{~kg}$ NPSB (11498 kg ha-1), 250 kg NPSB (11325 kg ha-1) and $300 \mathrm{~kg}$ NPSB (12009 kg ha-1) (Table 7). The highest result of Wane and Kingbird was improved by $62.3 \%$ and $55.8 \%$ respectively as compared to the lowest biomass produced on the control of each; and by $48.2 \%, 42.3 \%$ and $31.8 \%, 16.3 \%$ as compared to recommended NPSB alone and recommended NP for both varieties respectively. Even though the application of recommended NPSB without supplementary urea and recommended NP fertilizer rate the production were low. Increasing the application of blended fertilizer rates increase the growth, vegetative condition and the production of yield and above ground biomass yield of bread wheat varieties in the experimental site. The application of fertilizer treatment rates were significantly improved the production of the biomass yield. According to Melkamu $\mathrm{H}$ [45] blended fertilizer supply had a marked effect on the aboveground biomass, grain yield, and straw yield. Jasemi, et al. [46] reported vegetative growth and biological yield has much dependence to consumption of chemical fertilizers, application of the fertilizers led to increasing biological yield of wheat.

\begin{tabular}{|c|c|c|c|c|}
\hline \multirow{3}{*}{ Fertilizer rates $\left(\mathrm{kg} \mathrm{ha}^{-1}\right)$} & \multirow{2}{*}{\multicolumn{2}{|c|}{$\begin{array}{c}\text { GY }\left(\mathrm{kg} \mathrm{ha}^{-1}\right) \\
\text { Varieties }\end{array}$}} & \multirow{2}{*}{\multicolumn{2}{|c|}{$\begin{array}{c}\text { BY }\left(\mathrm{kg} \mathrm{ha}^{-1}\right) \\
\text { Varieties }\end{array}$}} \\
\hline & & & & \\
\hline & Wane & Kingbird & Wane & Kingbird \\
\hline $0 \mathrm{~kg} \mathrm{~F} \mathrm{ha}^{-1}$ & $2165^{\mathrm{h}}$ & $1991^{\mathrm{h}}$ & $5302^{\mathrm{i}}$ & $5053^{i}$ \\
\hline $150 \mathrm{~kg}$ TSP + $158.7 \mathrm{~kg} \mathrm{Urea} \mathrm{h}^{-1}$ & $3562^{\text {cde }}$ & $3647^{\text {cde }}$ & 9581de & $10167^{\mathrm{cd}}$ \\
\hline $100 \mathrm{~kg}$ NPSB + 0 kg Urea ha-1 & $2806^{g}$ & $2832^{\mathrm{fg}}$ & 7283gh & $6923^{\mathrm{h}}$ \\
\hline $100 \mathrm{~kg}$ NPSB $+100 \mathrm{~kg}^{\prime}$ Urea ha $^{-1}$ & $3425^{\mathrm{de}}$ & $3252^{e f}$ & $8749^{\text {ef }}$ & $8108^{\mathrm{fg}}$ \\
\hline $150 \mathrm{~kg}$ NPSB $+100 \mathrm{~kg}^{2}$ Urea ha ${ }^{-1}$ & 3489de & $3375^{d e}$ & $9905^{d}$ & $8691^{\text {ef }}$ \\
\hline $200 \mathrm{~kg}$ NPSB + $100 \mathrm{~kg}^{\text {Urea ha }}{ }^{-1}$ & $3966^{\mathrm{abc}}$ & $3737 \mathrm{bcd}$ & $11281^{b c}$ & $11498^{b}$ \\
\hline $250 \mathrm{~kg}$ NPSB $+100 \mathrm{~kg}^{-}$Urea ha $^{-1}$ & $4107 \mathrm{ab}$ & 3499de & $12392^{\mathrm{b}}$ & $11325^{b}$ \\
\hline $300 \mathrm{~kg}$ NPSB $+100 \mathrm{~kg}^{-}$Urea ha $^{-1}$ & $4236^{a}$ & $3682^{\text {cd }}$ & $14053^{a}$ & $12009^{b}$ \\
\hline Grand mean & \multicolumn{2}{|c|}{3361} & \multicolumn{2}{|c|}{9520} \\
\hline LSD (5\%) & \multicolumn{2}{|c|}{421.03} & \multicolumn{2}{|c|}{1136.1} \\
\hline P Value & \multicolumn{2}{|c|}{$<.0001$} & \multicolumn{2}{|c|}{$<.0001$} \\
\hline CV (\%) & \multicolumn{2}{|c|}{7.53} & \multicolumn{2}{|c|}{7.18} \\
\hline
\end{tabular}

Table 7: Mean values of the interaction effect of blended fertilizer rates and bread wheat varieties on grain yield and above ground Biomass Yield.

GY: Grain yield; BY: Biomass yield; TSP: Triple Super Phosphate; NPSB: Nitrogen Phosphorus Sulfur and Boron; LSD: Least Significant Difference; CV: Critical Value. Means followed by the same letter(s) within a column are not significantly different from each other at $5 \%$ level of significance, ns: Not significant [47].

\section{Conclusion and Recommendation}

The results of growth and yield attribute investigations showed that Wane variety had better performances as compared to Kingbird variety and interaction of varieties to NPSB fertilizer for the number of productive tillers, above ground biomass yield and grain yield had good performances at $300 \mathrm{~kg}$ ha-1NPSB fertilizer treatment with supplementary urea on Wane variety; but at $200 \mathrm{~kg}$ NPSB fertilizer applied with supplementary urea from Kingbird. Therefore, application of NPSB at the rate of 300 $\mathrm{kg}$ NPSB ha- 1 in the production of Wane and 200 NPSB kg ha-1 in the production of Kingbird varieties was economically beneficial and recommended for around Kulumsa area. In the future for keeping the soil health and improve the production of the yield, use of balanced nutrient application (macro and micro) for the farmer land is so important. Since this study was conducted in one location for one season, it should be repeated in more location and season for further recommendation in similar agro ecologies.

\section{Acknowledgment}

The authors are grateful to Mrs Gadisa Alemu, Tafesse Solomon, Mengistu Chemeda and Anbese Debebe for their 
assistance in trials management and data collection, and also thanks Kulumsa soil Laboratory staff members for soil sample preparation and analysis the result. The research was funded by Ethiopian Institute of Agricultural Research.

\section{References}

1. Mehraban A (2013) The Effect of Different levels of Manure and Micro-nutrients on Yield and Some Physiological Properties of Spring Wheat. Technical J Engineering Appl Sci 3(22): 3102-3106.

2. Abeyo B, Braun H, Singh R, Ammar K, Payne T, et al. (2012) The performance of CIMMYT wheat germplasm in East Africa with special emphasis on Ethiopia. In: Book Abstracts of Wheat for Food security in Africa, Quilligan E, et al. In: (Eds.), conference AA, Ethiopia, pp: 22.

3. CSA (2018) Report on Area and Production of Major Crops (Private Peasant Holdings, Meher Season): Agricultural Sample Survey. $1^{\text {st }}$ (Vol.), Statistical bulletin 586, CSA, April 2018, Addis Ababa, Ethiopia.

4. Amanuel G, Kuhne RF, Tanner DG, Vlek PLG (2002) Recovery of 15- N labeled urea applied to wheat in the Ethiopian Highlands as affected by P fertilization. J Agron Crop Sci 189(1): 30-38.

5. Fayera A, Muktar M, Adugna D (2014) Effects of different Rates of NPK and Blended Fertilizers on Nutrient Uptake and Use Efficiency of Teff [Eragrostis Tef (Zuccagni) Trotter] in Dedessa District, Southwestern Ethiopia. J Biol Agric Healthcare 4(25): 254-258.

6. Assefa M, Johnson MRS, Nyambilila A, Tekalign M (2015) Wheat Response to Applied Nitrogen, Sulfur, and Phosphorous in three Representative Areas of the Central Highlands of Ethiopia. In J Plant Soil Sci 8(5): $1-11$.

7. Nyamangara J, Gotosa J, Mpofu SE (2001) Cattle manure effects on structural stability and water retention capacity of granitic sandy soil in Zimbabwe. Soil and Tillage Research 64(3-4): 157-162.

8. Tolera A, Feyisa D, Friesen DK (2009) Effects of Crop Rotation and N-P Fertilizer Rate on Grain Yield and Related Characteristics of Maize and
9. Zerihun A, Sharma JJ, Nigussie D, Fred K (2013) The effect of integrated organic and inorganic fertilizer rates on performances of soybean and maize component crops of a soybean/maize mixture at Bako, Western Ethiopia. Afr J Agric Res 8: 3921-3929.

10. Kombiok JM, Buah SSJ, Segbedji JM (2008) Enhancing Soil Fertility for Cereal Crop Production through Biological Practices and the Integration of Organic and In-Organic Fertilizers in Northern Savanna Zone of Ghana. Soil Fertility.

11. Fassil K, Charles Y (2009) Soil Fertility Status and Numass Fertilizer Recommendation of Typic Hapluusterts in the Northern Highlands of Ethiopia. World Appl Sci J 6(11): 1473-1480.

12. Bai Z, Dent D, Olsson L, Schaepman M (2008) Proxy global assessment of land degradation. Soil Manag 24(3): 223-234.

13. Cobo J, Dercon G, Cadisch G (2010) Nutrient balances in African land use systems across different spatial scales: a review of approaches, challenges and progress. Agri Ecosys Environ 136(1-2): 1-15.

14. ATA (Agricultural Transformation Agency) (2016) Soil Fertility Status and Fertilizer Recommendation Atlas of the Southern Nations Nationalities and Peoples' Regional.

15. EthioSIS (Ethiopian Soil Information System) (2014) Soil Fertility and Fertilizer recommendation Atlas of Tigray Region. Ministry of Agriculture (MoA) and Agricultural Transformation Agency (ATA).

16. Bray RH, Kurz LT (1945) Determination of total, organic and available forms of phosphorous in soil. Soil Sci 59(1): 39-45.

17. Landon JR (1991) Booker Tropical Soil Manual: a handbook for soil survey and agricultural land evaluation in the tropics and subtropics. John Wiley \& Sons Inc., New York.

18. AACC (American Association of Cereal Chemists) (2000) Approved Methods of the American Association of Cereal Chemists. AACC, St. Paul, MN.

19. SAS Institute (2002) SAS/STAT User's Guide, Version 9.0. SAS institute In Crit Cary Nol Ne. Western Oromia, Ethiopia. East
Diriba Shiferaw G, et al. Effects of Blended Fertilizer Rates on Bread Wheat (Triticum Aestivum L.) Varieties on Growth and Yield Attributes. J Ecol \& Nat Resour 2019, 3(3): 000170.
Copyright $\subset$ Diriba Shiferaw G, et al. 
20. Ethiopian Soil Information System (EthioSIS) (2013) Towards improved fertilizer recommendations in Ethiopia-Nutrient indices for categorization of fertilizer blends from EthioSIS woreda soil inventory data. Adiss ababa, Ethiopia.

21. Sahlemdhin Sertsu (1999) Draft guideline for regional soil testing laboratory. NFIA, Addis Ababa, Ethiopia.

22. Seyfu Ketema (1993) Tef [Eragrostis tef (Zucc) Trotter]. Breeding genetics resources, agronomy, utilization and role in Ethiopian Agriculture.

23. Tekalign Tadesse (1991) Soil, plant, fertilizer, animal manure and compost analysis manual. International Livestock centre for Africa, No. B13. Addis Ababa, Ethiopia.

24. Azlan A, Aweng ER, Ibrahim CO, Noorhaidah A (2012) Correlation between Soil Organic Matter, Total Organic Matter and Water Content with Climate and Depths of Soil at Different Land use in Kelantan, Malaysia. J Appl Sci Environ Manag 16(4): 353-358.

25. Masresha Mitiku (2014) Response of Maize (Zea mays L.) to Application of Mineral Nitrogen Fertilizer and Compost in Godere District, Gambella Region, Southwestern Ethiopia. Haramaya University, Ethiopia.

26. Habtamu A, Heluf G, Bobe B, Enyew A (2015) Effects of Organic and Inorganic Fertilizers on Yield and Yield Components of Maize at Wujiraba Watershed, Northwestern Highlands of Ethiopia. Ame J Plant Nutrition Fertilization Technol 5(1): 1-15.

27. White RE (1997) Principles and practices of soils science: The soil is the natural resource.

28. Mohammed YA, Kelly J, Chim BK, Rutto E, Waldschmidt $K$, et al. (2011) Nitrogen Fertilizer Management for Improved Grain Quality and Yield in Winter Wheat in Oklahoma. Journal of Plant Nutrition 36(5): 749-761.

29. Bekalu Abebe, Mamo Manchore (2016) Effect of the rate of $\mathrm{N}$ fertilizer application on growth and yield of wheat (Triticum aestivum L.) at Chencha, Southern Ethiopia. International Journal of Plant, Animal and Environmental Sciences 6(11): 111-122.

30. Marschener (1995) Mineral nutrition of higher plants. $2^{\text {nd }}($ Edn.), Academic press, London, pp: 398.

Diriba Shiferaw G, et al. Effects of Blended Fertilizer Rates on Bread Wheat (Triticum Aestivum L.) Varieties on Growth and Yield Attributes. J Ecol \& Nat Resour 2019, 3(3): 000170.
31. Tanaka A (1994) Plant characters related to Nitrogen response in rice. The mineral nutrition of the rice plant, Proceedings of the rice plant. Food and Agriculture Policy Research Center Tokyo, pp: 334439.

32. Ali L, Mdy-Ud-Din Q Ali M (2003) Effect of different doses of nitrogen fertilizer on yield of wheat. Int J Agric Biol 5(4): 438-439.

33. Tayebeh A, Abbas A, Seyed AK (2011) Wheat yield and grain protein response to nitrogen amount and timing. AJCS 5(3): 330-336.

34. Sofonyas Dargie (2016) Response of bread wheat (Triticum Aestivum L.) to application of slow releasing nitrogen fertilizer in Tigray, Northern Ethiopia, a thesis (M.Sc.), The School of Graduate Studies, Alemaya University, and Ethiopia, pp: 45.

35. Abdullatif M, Asmat UM, Sattar A, Fiaz Hussain, Abbas G, et al. (2010) Response of growth and yield of wheat to NPK fertilizer. Sci Int (Lahore) 24(2): 185-189.

36. Bereket Haileselassie, Dawit Habte, Mehretab Haileselassie, Gebremedhin Gebremeskel (2014) Effects of mineral nitrogen and phosphorus fertilizers on yield and nutrient utilization of bread wheat (Tritcum aestivum) on the sandy soils of Hawzen District, Northern Ethiopia. Agri Forestry Fisheries 3(3): 189-198.

37. Abdollahi GJ, Hashemi-majd K, Mosavi SB, Feiziasl V, Jafarzadeh J, et al. (2012) Effects of fall nitrogen rates on rainfed bread wheat yield and yield components in drought condition. Int Res J Applied Basic Sci 3(11): 2195-2204.

38. Tahir MA, Tanveer TH, Shah NF, Wasaya A (2009) Yield response of wheat (Triticum aestivum L.) to boron application at different growth stages. Pakistan J Life Social Sci 7(1): 39-42.

39. Muhammad T, Asefa T, Tajamol H, Wasoya A (2009) Yield response of wheat to Boron application. Pak J Life Soc Sci 7(1): 39-42.

40. Shuaib K, Muhammad A, Anjum MA, Ahmad S, Ghulam A, et al. (2009) Effect of phosphorus on the yield and yield components of wheat variety under rain fed conditions. Sarhad J Agri 25(1): 21-24. 
41. Jemal Abdulkerim, Tamado Tana, Firdissa Eticha (2015) Response of Bread Wheat (Triticum aestivum L.) Varieties to Seeding Rates. Asian J Plant Sci 14(2): 50-58.

42. Taye Bekele, Yesuf Assen, Sahlemedhin Sertsu, Amanuel Gorfu, Mohammed Hassena, et al. (2002) Optimizing fertilizer use in

43. Marcelo Curitiba Espindula, Valterley Soares Rocha, Moacil Alves de Souza, Marcela Campanharo, Guilherme de Sousa Paula (2013) Rates of urea with or without urease inhibitor for topdressing wheat. Chilean J Agri Res 73(2).

44. Mulugeta Eshetu, Shure Sebboka, Tilahun Chibsa, Chala Chimdessa, Negash Bedasso (2017) Optimization of Fertilizer Recommendations for Bread Wheat at Sinana District of Bale Zone,
Southeastern Oromia, Ethiopia. Int J Sci Qualitative Analysis 3(6): 55-60.

45. Melkamu H, Gashaw M, Wassie H (2019) Effects of different blended fertilizers on yield and yield components of food barley (hordeum vulgare l.) on nitisols at hulla district, southern Ethiopia. Academic

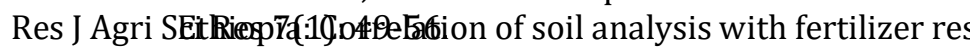

46. Jasemi SS, Akbari GA, Akbari GA, Najafian G, Moradi F (2014) Nutrition management effects on grain yield, yield components and some physiological characteristics of bread wheat cultivars. Int J Agronomy Agri Res 5(3): 1-6.

47. Ankerman D, Large R (SD) Agronomy handbook, soil and plant analysis, A and L. Agricultural Laboratories. Memphis, USA. 